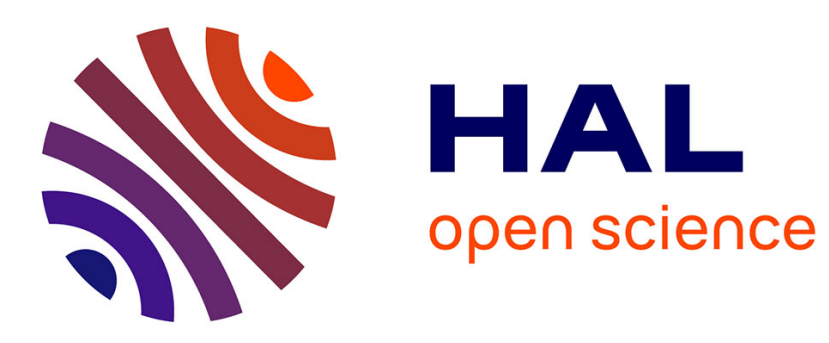

\title{
Was Canguilhem a Biochauvinist? Goldstein, Canguilhem and the Project of Biophilosophy
}

\author{
Charles T. Wolfe
}

\section{To cite this version:}

Charles T. Wolfe. Was Canguilhem a Biochauvinist? Goldstein, Canguilhem and the Project of Biophilosophy. Darian Meacham. Medicine and Society, New Perspectives in Continental Philosophy, 120, Springer, pp.197-212, 2015, Philosophy and Medicine 978-94-017-9870-9. 10.1007/978-94-0179870-9_12. hal-02070003

\section{HAL Id: hal-02070003 https://hal.science/hal-02070003}

Submitted on 26 Mar 2019

HAL is a multi-disciplinary open access archive for the deposit and dissemination of scientific research documents, whether they are published or not. The documents may come from teaching and research institutions in France or abroad, or from public or private research centers.
L'archive ouverte pluridisciplinaire HAL, est destinée au dépôt et à la diffusion de documents scientifiques de niveau recherche, publiés ou non, émanant des établissements d'enseignement et de recherche français ou étrangers, des laboratoires publics ou privés. 


\title{
Was Canguilhem a biochauvinist? Goldstein, Canguilhem and the project of biophilosophy *
}

\author{
Charles T. Wolfe \\ Sarton Centre for History of Science, \\ Dept. of Philosophy and Moral Sciences \\ Ghent University \\ Unit for History and Philosophy of Science, University of Sydney \\ charles.wolfe@ugent.be \\ Draft submission for Darian Meacham, ed., \\ Medicine and Society, New Continental Perspectives \\ (Springer, forthcoming)
}

\begin{abstract}
Georges Canguilhem is known to have regretted, with some pathos, that Life no longer serves as an orienting question in our scientific activity. He also frequently insisted on a kind of uniqueness of organisms and/or living bodies their inherent normativity, their value-production and overall their inherent difference from mere machines. In addition, Canguilhem acknowledged a major debt to the German neurologist-theoretician Kurt Goldstein, author most famously of The Structure of the Organism in 1934; along with Merleau-Ponty, Canguilhem was the main figure who introduced the work of Goldstein and his 'phenomenology of embodiment' into France. In this paper I inquire if we should view Canguilhem and Goldstein as 'biochauvinists', that is, as thinkers who consider that there is something inherently unique about biological entities as such, and if so, of what sort.
\end{abstract}

\footnotetext{
${ }^{*}$ Versions of this paper have been presented at the Workshop on The Normal and the Pathological, University of Warwick, September 2011; Canguilhem's Philosophy of Life, KU Leuven, June 2012. I thank the organizers and audiences of those events, and Pierre-Olivier Méthot for their helpful comments.
} 
Nous n'avons pas l'outrecuidance de prétendre rénover la médecine en lui incorporant une métaphysique

(Canguilhem 1972, p. 9).

la vie déconcerte la logique

(Canguilhem 1977, p. 1)

In what follows I reflect on the possible contribution of Georges Canguilhem (1904-1995) to a discourse in the philosophy of the life sciences which would not be content to locate itself squarely within either of two classic and enduring orthodoxies: reductionism or holism. Granted, these two extremes often coxist, if not very happily, and the different subdisciplines approach them in a very different way. As Gayon has noted (Gayon 2010), the philosophy of biology as a professional discipline, which primarily focuses on a kind of specialized conceptual analysis aiming at clarifying the implications and consequences of biological claims in mainstream science, has kept a safe distance from what it perceives as 'vitalism' throughout its existence as an Anglophone genre. This is less true of the philosophy of medicine, inasmuch as it focuses more on 'whole person' analyses, subjectivity, qualitative dimensions of suffering and well-being, and so on (see Giroux 2010 for a useful contrast between Canguilhem and analytic philosophy of medicine).

Canguilhem was a prominent figure in these disciplines, particularly in the rather short-lived intellectual formation known as 'biophilosophy' (along with Raymond Ruyer and Gilbert Simondon; Ruyer's early works are contemporary with Canguilhem's, in the 1940s, while Simondon shares with Canguilhem a 'heyday' in the 1960s). The latter precisely was the project to understand Life, living beings, the concept of organism, and so on, in terms not exclusively dictated either by mechanistic science or by the philosophical fellow-travellers of such science. The question of whether such a project is necessarily 'vitalistic' or 'biochauvinist' (to use a recent coinage by the 
biological theorist and embodied-cognition researcher Ezequiel Di Paolo, in Di Paolo 2009), and of course, what these terms mean in the present context, shall be part of my concern in this essay.

Canguilhem sometimes described himself as a vitalist - playfully, but perhaps not ironically (Canguilhem 1965 and Canguilhem 1977, Preface), and one should not forget that in the decades he did so, particularly the 1950s1960s, it was at the very least provocative (Geroulanos 2009); there was after all no scholarship either on eighteenth-century vitalism (like that of the Montpellier School) or on early nineteenth-century German biology (like Blumenbach's embryology), nor of course was there such a thing as 'theory' and its invocations of vitalism (such as Bennett 2010b). Canguilhem returned to the theme several times, and of course in a broader sense if we reflect on some of the core arguments of his classic, The Normal and the Pathological, we find an implicit presupposition that normativity is a power or capacity proper to living beings. This may not be full-blown 'vitalism' (whatever that is; see Wolfe 2011a and 2011b; Normandin and Wolfe, eds. 2013), but it is an insistence that there is something unique about living entities that makes them creators of a certain world which they inhabit.

This should not be taken so much in the sense of classical idealism, for which "nothing whatsoever can have a positive relation to the living being if the latter is not in its own self the possibility of this relation, i.e. if the relation is not determined by the Notion and hence not directly immanent in the subject" (Hegel 1817/1970, § 359R, p. 385); it is closer for instance to von Uexküll's sense of Umwelt, according to which "Every subject spins out, like the spider's threads, its relations to certain qualities of things and weaves them into a solid web, which carries its existence" (von Uexküll 2010, p. 53). But we can also detect in this idea of living beings as creators, some Nietzschean overtones or arrière-pensées (and of course Foucault pointed to this aspect in his mentor's work, emphasizing that "forming concepts is a way of living, not of killing life, of living in complete mobility and not immobilizing life" [Foucault 1985/1989, p. 21]): the idea that values, norms and other 
higher-level constructs are in fact products of our vital instincts. For Canguilhem, who was interested in such illustrations of the unpredictability of life as monsters, "Man is only truly healthy when he is capable of multiple norms, when he is more than normal. The measure of health is a certain capacity to overcome organic crises in order to establish a new physiological order, different from the initial order. In all seriousness, health is the ability [le luxe] to fall ill and then get over it. On the contrary, illness is the reduction of the power to overcome other illnesses." 1

Closer to the present topic, we can also recognize in this idea the influence of Kurt Goldstein, who elaborated, in his lengthy and difficult work on 'the structure of the organism' (Goldstein 1934/1995), a conception of organisms as interpretive and indeed meaning-creating beings; beings for whom being alive, acting, is, aside from other metabolic processes, also a process of the production of meaning. Or, in a more recent restatement of the same core idea: "organisms are subjects having purposes according to values encountered in the making of their living" (Weber and Varela 2002, p. 102). Differently put, the kind of vitalism at work in Goldstein and Canguilhem is explicitly not like the vitalism of those people who contemplate little squiggly bundles of life (from Trembley's polyp to Driesch's sea urchin blastomeres, via Réaumur's frogs which he made to wear little taffetas shorts to catch their sperm) and then assert that they have witnessed the difference between Life and non-Life: "A vitalist, I would suggest, is someone who is led to reflect on the nature of life more because of the contemplation of an egg than because she has handled a hoist or a bellows" (Canguilhem 1965a, p. 88). Rather, it is a vitalism of meaning and projection.

Yet Canguilhem (unlike, say, Hans Jonas) is genuinely concerned with the nature of biological life, not with some secret way of defending human uniqueness over and against the rest of the physical universe. In his major collection of essays on the topic, The Phenomenon of Life, Jonas opposes the

\footnotetext{
1 "Le normal et le pathologique," in Canguilhem 1965b, p. 167. See also Canguilhem 1972, pp. $77,155$.
} 
world of conscious organisms to the 'dead' world of mechanical Nature and insists that "the point of life itself" is "its self-centered individuality," which he insists must be an "ontological concept" (Jonas 1966, p. 79); from the outset, he explains that he is interested in biological processes such as metabolism inasmuch as they are ultimately indicative of "freedom" (ibid., p. 3; see also Kass 1995). ${ }^{2}$ Indeed, vitalism has often served as a mask or indicator of humanism, itself often with theological foundations. That is, claims of an oppositional or differential sort, in which 'Life', 'organism', 'the animal' or 'the living body' are opposed, often in foundationalist ontological terms, to 'physical nature', 'mechanical nature', 'mechanistic materialism', 'the world as machine' and so on, like Carolyn Merchant's Death of Nature (Merchant 1980; see Sutton and Tribble 2011 for an inspiring critique) often in the end have an anthropocentric motivation such as defending freedom, as in Jonas' case above, or those thinkers for whom materialism and scientific analysis are suitable for "the material universe" but "yield disastrous results when applied to the inner, subjective world of human nature, human thought, and human emotions" (Hill 1968, p. 90). In contrast, Canguilhem was a naturalist, to use a term of art popular from the last decades: he approvingly quotes Spinoza asserting that we are parts of Nature and nothing more: we, as humans, or rational agents, or possessors of a pineal gland, do not form an imperium in imperio (Canguilhem 1965a, p. 95).

But my question here is, in what way does Canguilhem argue, biochauvinistically, for living bodies being special? One of the curious features of Goldstein's account we find again in Canguilhem's unique way of engaging with 'organisms' and the question of their uniqueness: the way in which he wavers or moves back and forth between a cautious, epistemological position (reminiscent of the Kantian regulative ideal in the third Critique) in which

\footnotetext{
${ }^{2}$ I am not suggesting that Jonas was a panpsychist, but rather that what interests him is not Nature per se, but conscious, self-maintaining organisms as such - and then, by extension, a system which enables such organisms to exist (thanks to Darian Meacham for demanding this clarification). A philosopher familiar with Hegel might recognize here a form of the philosophy of nature in which organisms are relevant inasmuch as they are (weak, or provisional) forms of subjectivity, and ultimately of Spirit.
} 
organisms are real and special because of the way we cognitively constitute them, and a bold, ontological position in which organisms are real because of basic, intrinsic features which are just there. (I shall not go into the details of Goldstein's account, which sounds more Heideggerian than anything else - for example, the claim in his "Concluding Remarks" that "the organism is a being enduring in time," curiously enough "in eternal time, for it does not commence with procreation, certainly not with birth, and does not end with death" although to be fair these 'existential' motifs crop up in Canguilhem too ${ }^{3}$.) But if we set that aside, Goldstein definitely contributed a new kind of approach which was, of course, holistic and organismic while nevertheless operating at a primarily heuristic, non-ontological level. As he says, "The Organism consists mainly of a detailed description of the new method, the so-called holistic, organismic approach. [...] We were confronted then with a difficult problem of epistemology. The primary aim of my book is to describe this methodological procedure in detail, by means of numerous observations" (Goldstein 1934/1995, p. 18).

However, this convenient distinction between the epistemological (projective, constitutive) vision of biological entities and the ontological vision (strong vitalist, 'rational metaphysics' as Kant might have said), is somewhat muddied when Canguilhem introduces a further vitalist twist: that it might be an objective ('ontological') feature of living beings (i) that they are interpretive beings, à la Goldstein, and especially (ii) that they need to consider other entities as themselves organismic, purposive, vital (Canguilhem 1965a). There is also an existentialist parfum in Canguilhem's reflections (a further twist on the ontological dimension in [i]), when he describes this interpretive stance as essentially a kind of fundamental existential attitude. ${ }^{4}$ One finds the properly biological or biomedical version of this 'existentialism' in The Normal and the Pathological, with statements such as "the life of a living being . . . only

\footnotetext{
${ }^{3}$ Goldstein 1934/1995, p. 387.

${ }^{4}$ For more on the young Canguilhem as a humanist existentialist, a reader of Alain, prior to his turn to vitalism, see the precise analysis in Bianco 2013.
} 
recognizes the categories of health and illness on the level of experience, which is first of all an épreuve in the affective sense of the term - not on the level of science" (Canguilhem 1972, p. 131). We should notice here the appeal to a founding, subjective, dimension, although it is not clear if this should be treated as an ontologically specific region or not. That is, Canguilhem is neither listing 'objective features' of living beings, like homeostasis, and claiming that they are 'definitory', nor, conversely, is he opting for a fully subjectivist position, where 'to live' is understand on the model of, or as interrelated with, 'to know' as the property of a knowing subject. Is he closer to a Hegelian perspective, in which the organism is already a form of subjectivity? Again, this is not the place to decide such matters.

If we try to understand Canguilhem in relation to recent theoretical biology (including the 'organizational' theories of A. Moreno et al., see Bechtel 2007, Mossio and Moreno 2010, Moreno and Mossio forthcoming), using as a guiding question, 'are organisms unique in the physical world? If so, why?', we arrive at a curious situation, in which he seems to be both more and less committed to the uniqueness of embodied, biomedical entities than other theoreticians. On the one hand, Canguilhem appears more cautious, and less crypto-dualistic than some prominent recent figures like Varela, who tend to fall into the category mistake of seeking to prove the uniqueness of the biological by providing some empirical criteria - a 'laundry list', as it were, which frequently invokes Bernard's milieu intérieur, Cannon's notion of homeostasis, and more recently the work of Ganti, Luisi et al. on selforganization and autocatalytic processes (and organizational closure). ${ }^{5}$ This is particularly odd when some of these figures invoke the authority of Kant in the Third Critique (as has become very common in this strand of theoretical biology, e.g. Weber and Varela 2002; Perret 2012; Simeonov, Brezina et al.

\footnotetext{
${ }^{5}$ For a rare acknowledgment of this problem, see Di Paolo 2009, where he criticizes Varela for "a hazy view of living systems as being defined by a list of properties (growth, reproduction, responsiveness" (p. 14). A nice extension of this point is in Machery 2012 (see especially his critical evaluation of those he calls "life definitionists," who "have constantly mixed folk intuitions with scientific considerations," p. 161).
} 
2012). To put it bluntly, to provide an empirical set of criteria for why living beings are special and to claim that this fills in a Kantian framework, is not a good idea if this framework explicitly rejects the idea of giving empirical definitions of organism, inasmuch as Kant's organism concept is explicitly built around his notion of regulative ideal (Kant 1790/1987, § 73, 276; Wolfe 2010). For Kant, organism is a "reflective" construct rather than a "constitutive" feature of reality, and reflective judgments are "incapable of justifying any objective assertions" (Kant 1790/1987, § 67, 259; § 73, 277).

Kurt Goldstein and Canguilhem were, I think, onto something when they insisted that rather than say what is unique about the biological, we look to the observer: to be an organism is to have a point of view on organisms; one which produces intelligibility, which reveals organisms as meaning-producing beings (Starobinski 1956, who comments that "comprendre nous met en présence d'une totalite signifiante" 6 ). Notice that this approach valorizes a constructivist dimension in the definition of life and the relevant individual (like the World Health Organization's notorious definition of health, which is broad enough to include all senses of well-being: "Health is a state of complete physical, mental and social well-being and not merely the absence of disease or infirmity"7). That is, there may be biological 'facts' or 'invariants', but we are makers of our worlds. (Who is this 'we'? Humans? Higher mammals? All living creatures? Canguilhem is never very clear how restrictive this concept is: like von Uexküll's Umwelt, could it apply to ticks and woodlice? He sometimes grants that "even for an amoeba, living means preference and exclusion," using the same phrase later in the book: "the life of a living entity, even an amoeba, only acknowledges the categories of health and sickness on the level of experience" (Canguilhem 1972, pp. 84, 131, emphasis mine). But most of

\footnotetext{
${ }^{6}$ Starobinski 1956, p. 5; the extent to which this includes non-human animals is open to discussion.

${ }^{7}$ Preamble to the Constitution of the World Health Organization as adopted by the International Health Conference, New York, 19-22 June, 1946; signed on 22 July 1946 by the representatives of 61 States (Official Records of the World Health Organization, no. 2, p. 100) and entered into force on 7 April 1948. The definition has not been amended since 1948 .
} 
the time he is interested in humans as subjective, embodied agents - the objects of medical science, caught between biological and social norms. And this is why I suggest that he can be called a humanist.)

But on the other hand, this is not the final answer, or the argumentstopper: as I mentioned above, Canguilhem is also more biocentric or biochauvinistic than many of his contemporaries. This appears more clearly if we contrast Canguilhem with the fairly 'disembodied' character of much of recent theoretical biology: in contrast, he wants to be a kind of vitalist. To be sure, Canguilhem is not the sort of thinker who seeks to discover 'organismic laws' (like Elsasser 1961), lays out a laundry list of ontologically unique features, or most crudely, propounds a metaphysics of entelechies, like Hans Driesch, who converted his Chair in biology into one in philosophy in order to reinvent a jejune Aristotelianism based on his earlier experimental work in Entwicklungsmechanik (which Erik Peterson has described, fittingly, as 'bioexceptionalism' [Peterson 2012, 2013]: an empire within an empire or 'kingdom within a kingdom, as it were): a metaphysics of the sea urchin.

To be more precise, Driesch, who came out of the school of Wilhelm Roux's Entwicklungsmechanik (or study of the mechanisms of the developmental process), performed successful, and much-discussed experiments with sea urchin eggs, halving the two blastomeres (daughter cells) of the egg and successfully producing two whole embryos and larvae, complete in every respect. This total equality of the halved eggs he termed their "totipotency," and the cells derived from the egg he termed a harmonious equipotential system (Driesch 1914, p. 209). Faced with the evidence that there was no physical structure we can find in the sea urchin embryo which is responsible for the "regulative" or "equipotential," force, he felt obliged to posit a vital force, the entelechy. ${ }^{8}$ Tellingly, Driesch became so absorbed with this

\footnotetext{
${ }^{8}$ I note that Bergson (who was sometimes wrongly associated with Driesch under the banner of vitalism in the early twentieth century), attacked this claim of a life-force in all living organisms explicitly. Bergson asked: where is this force? at what level? He expressed doubts that nature could be interpreted strictly in terms of this internal "finality" ( Wolsky \& Wolsky 1992, p. 156f.)
} 
feature that he gave up experimental work to teach philosophy at the University of Leipzig, developing a form of vitalism, as he called it, focusing on the idea that entelechies exist in all living organisms. The choice of term was deliberate, for he believed one had to revive a vitalist thinking which had lain dormant since Aristotle (the Montpellier school does not appear in his historical surveys). Canguilhem comments on Driesch's 'shift' from science to metaphysics as follows:

The vitalist biologist who turns philosopher of biology thinks he brings a certain capital with him to philosophy, but in reality he brings to it only a land-income [rentes], which continually decreases in the market of scientific values - for the simple reason that research, in which he no longer participates, continues to move forward. Such is the case with Driesch's abandonment of scientific research for philosophical speculation and even teaching. What we have here is an unpremeditated abuse of confidence. The prestige of scientific work stems above all from its internal dynamism. The former scientist sees himself deprived of tills prestige in the eyes of active scientists. He believes he will preserve it among the philosophers. This must not be so. Philosophy, being an autonomous enterprise of reflection, does not honor any prestige at all, not even that of the scientist, or - even more rightly - that of the exscientist (Canguilhem 1965a, p. 94; I have used the translation in Canguilhem 2008a, pp. 68-69).

Canguilhem is not a metaphysician of entelechies, then; nor is he a quasi-religious defender of the sovereignty of organic life like Hans Jonas or his more simplistic disciple Leon Kass (Kass 1995); nor a defender of philosophical anthropology like Helmuth Plessner (here I refer back to my comment regarding the hidden or overt foundationalism in such forms of vitalism). In some respects, particularly in his 1966 essay "Le concept et la vie," which begins with a long reflection on Aristotle, he seems closer to Marjorie Grene and her attempt to return to Aristotelian teleology (Grene 1968, 1974; Grene herself wrote favorably about Canguilhem: Grene 2000). Unlike many of these thinkers, as well as phenomenologists of embodiment, Canguilhem has no appeal to a Romantic subjectivity, e.g. in the sense described (critically) by Jean-Marie Schaeffer: "In phenomenology, the understanding of embodiment (corporéité) is part of an approach that 
continues to accept the epistemic privilege of consciousness's self-investigation as axiomatic" or (affirmatively) by the enactivist theorist Evan Thompson: "Life realizes a kind of interiority, the interiority of selfhood and sense-making." 9 In explicit contrast to Varela and most of the above-mentioned thinkers (with the exception of Grene), Canguilhem does not have any problems with Darwinian evolution (Canguilhem 1972, p. 90; Méthot 2013), and indeed is not engaged in the project of 'refounding', 'regrounding' or otherwise reinventing a new program for science (with occasional, late exceptions which display a more reactive attitude towards the march of science, such as his remarks against some of psychology, cognitive science and cognitive neuroscience in the essay "Le Cerveau et la Pensée" [Canguilhem 1980/1992], which themselves extend criticisms already articulated in Canguilhem 1958/2002). But is he still a 'biochauvinist', claiming that there is a special "biological space and time"?

All of this is really quite 'dialectical', in the sense of being slippery, and almost circular - but in a productive sense. Namely, when a prominent figure like Andy Clark, who pushed cognitive science to take embodiment much more seriously in a variety of publications at least since Being There (Clark 1997), has to warn about the mysticism of "pressing the flesh" (Clark 2008), he is effectively stepping back from twenty years' worth of emphasis on what is unique about embodiment. When Di Paolo warns against the naïveté of "biochauvinism," ten pages later he speaks approvingly of another theorist (Michael Wheeler)'s concept of "vital materiality" (Di Paolo 2009, p. 20, referring to Wheeler 2010 [the paper had been available for some years earlier]). Wheeler had used this term in opposition to what he calls implementational materiality. Vital materiality is meant to convey the sense of the necessarily biological features of certain types of organization.

Similarly, just when Canguilhem has finished warning the reader about the intellectual dangers inherent in positing that living beings are like an empire within an empire (imperium in imperio, Canguilhem 1965a, p. 95), he

\footnotetext{
${ }^{9}$ Schaeffer 2007, p. 118; Thompson 2007, p. 238. Thompson often refers to 'sense-making' as a distinctive feature of enaction, in autopoietic systems (e.g. p. 139).
} 
will then assert - as he does at length in "Le concept et la vie," that it is Life itself - written with a very capital $\mathrm{L}$, that determines livings beings to act in these interpretive, purposive, normative, vital ways. Life "disconcerts logic" (Canguilhem 1977, p. 1). In a lecture in the problem of regulations in the organism and society, he says that

An organism is an entirely exceptional mode of being, because there is no real difference, properly speaking, between its existence and the rule or norm of its existence. From the time an organism exists, is alive, that organism is 'possible', i.e., it fulfills the ideal of an organism; the norm or rule of its being [existence] is given by its existence itself (Canguilhem 2002, pp. 106-107).

An "entirely exceptional mode of being" sounds like ontological specificity.

He states what I loosely called the dialectical slipperiness of the relation between Life itself and the thinker's vitalism more sharply in The Normal and the Pathological itself: "It is life itself, in its differentiation between its propulsive behavior and its repulsive behavior, which introduces the categories of health and illness into human consciousness. These categories are biologically technical and subjective, not biologically scientific and objective" (Canguilhem 1972, p. 150). Notice here the subjectivism - the appeal to a foundational subjectivity - which I had earlier connected to a particularly anti-naturalistic trend in phenomenology, and the more recent theory known as enactivism, associated with Varela in particular, which often asserts that life is lived 'outside of the physical': "Life is not physical in the standard materialist sense of purely external structure and function ... [w] accordingly need an expanded notion of the physical to account for the organism or living being" (Thompson 2007, p. 238). Indeed, Canguilhem himself, sounding less careful than usual, will sometimes say that "In short, it is impossible for the objectivity of medical knowledge to cancel out (annuler) the subjectivity of the lived experience of the patient" (Canguilhem 1978/2002, p. 409; this essay was added to the later edition of this book). Yet the subjectivity at issue is, to be fair, never disembodied, never some pure ego contemplating the reality of the flesh like a sailor in a ship. Where Canguilhem 
differs sharply from the phenomenology of embodiment is that the latter is permanently tempted by a foundationalist distinction between Leib as interiority and Körper as exteriority (as Schaeffer notes in the passage cited above). From Merleau-Ponty to Varela and Thompson, such thinkers maintain that the lived body (which really is the body in their discourse) exists at least in part "outside of physical space" (Merleau-Ponty 1963, p. 209). Thus the living body - indeed, any organism - "is an individual in a sense which is not that of modern physics" (ibid., p. 154).

Now, Canguilhem is in his own way, a thinker of embodiment, which I have noted in contrasting his view with both Driesch's (neo-)vitalism and Jonas's metaphysics of organism. But he has no need for these additional commitments to a "non-physical" dimension of Life. Indeed, I don't think Canguilhem, the medical doctor, would ever go as far as Deleuze and speak of a vitalism of the inorganic, a "powerful non-organic life," 10 or, as contemporary theorists might, of "a vitality intrinsic to materiality as such," wherein the author recommends "detach[ing] materiality from the figures of passive, mechanistic, or divinely infused substance" (Bennett 2010a, p. xiii). Life is too central for him - not life-forces or entelechies, not cosmic or impersonal life, but the life of embodied agents. Similarly, the particularly medical emphasis in his vitalism (manifest in his focus on Bichat and related figures), which can be conveyed in the basic claim that all living beings die and get sick, with the implied, irreducibly axiological dimension, distinguishes it from forms of vitalism predicated on embryology and its mysteries: "the patient is a Subject" (with a capital S, Canguilhem 1978/2002, p. 409; for more on Canguilhem on values and subjectivity, see Sholl, ms.). That is, a philosophical reflection on health and sickness, on the 'normativity' of the organism and its experience (Goldstein-Canguilhem) is at some distance from a reflection on the egg, its

\footnotetext{
${ }^{10}$ Deleuze 1993, p. 164 ("La vitalité non-organique est le rapport du corps à des forces ou puissances imperceptibles qui s'en emparent ou dont il s'empare"), and Deleuze and Guattari 1991, p. 172. In Francis Bacon, Logique de la sensation, the phrase "la vitalité non organique d'un corps sans organe" is partly credited to Wörringer and opposed to the phenomenological unity of the body (Deleuze 1981/2002, p. 31).
} 
potential and the metaphysics one can derive from it. Of course, not all scientific and theoretical reflections on the uniqueness of developmental systems need to appeal to a metaphysical uniqueness of life, even at their most holistic, organismic moments (Oyama 2010), and similarly, there is nothing inherently false about focusing on the unique features of biological systems, whether of the homeostatic sort (Bernard, Cannon, Luisi, Turner), the developmental (Oyama) or of the ecologically systemic sort (Odling-Smee). ${ }^{11}$

Conversely, and despite their shared affinity for Goldstein, it is more than unlikely that Canguilhem would verse into Catholic mysticism of the flesh, as Merleau-Ponty does in the Phenomenology of Perception: "Just as the sacrament not only symbolizes [...] an operation of Grace, but is also the real presence of God [...] in the same way the sensible has not only a motor and vital significance but is a way of being in the world [...] sensation is literally a form of communion."12 I think Canguilhem's advocating of a core Spinozist tenet (we are all parts of Nature, there is no kingdom within a kingdom), his Nietzschean position with regard to life as the production of value(s), and his Darwinian recognition of the role of chance and evolution, to name three basic features of his thought, put him at odds with the above doctrine. This is so, even if, commenting in fact on Merleau-Ponty in a late lecture on Health, Canguilhem reflects with what I think to be a hint of distance, regret or irony on the limitations of a conceptualization of the living body as "inaccessible to others, accessible only to its titular holder" (2008b, p. 476); that is, he has

\footnotetext{
${ }^{11}$ For some philosophical discussion of these various recent models in biology, see Barberousse, Morange \& Pradeu, eds., 2009 and Normandin and Wolfe, eds. 2013.

${ }^{12}$ Merleau-Ponty 1962, p. 212. Novalis already identified the experience and conceptual paradoxes of the sense of touch with "the mystery of transubstantiation" (Novalis 1798/1987, p. 622). This fascination with the flesh as somehow apart from the physical world is present, prior to Merleau-Ponty, in the Husserl of Ideas II, and later, in Didier Anzieu and his notion of the 'Moi-Peau', and Jean-Luc Nancy, with his 'secularized Christian' fascination with embodiment qua incarnation. They seem to repeat verbatim the powerful mystical utterances concerning a body beyond this world, of figures such as the twelfth-century nun Hildegard of Bingen and the thirteenth-century Flemish poet and Beguine, Hadewijch (Dailey 2011). Granted, it is possible to derive other positions from Merleau-Ponty, notably in his earlier work The Structure of Behavior.
} 
referred to "commentator after commentator" who ascribes superiority to what is given as such, acknowledging the existence of a side of the living body that is "inaccessible to others, accessible only to its titular holder" (ibid.).

This sense of privacy, of inaccessible interiority, is a crucial feature of many defenses of what organisms are and how they are different from machines: Leibniz for instance, for whom they differ from ordinary machines in possessing a "deeper source"13; or perhaps Kant when he stated rather confidently, and influentially, that "there will never be a Newton of a blade of grass" in the third Critique of 1790, having already claimed in the so-called 'pre-critical' Universal Natural History and Theory of the Heavens of 1755 that "we will sooner understand the formation of all celestial bodies, the cause of their motions, in short, the origin of the entire present arrangement of the world-edifice, than we will come to know distinctly or completely the production of a single herb or of a caterpillar from mechanical grounds." 14 This is what Schaeffer meant in the passage I cited above, when he refers to the understanding of embodiment that holds as foundational the "epistemic privilege" of a self-aware consciousness (Schaeffer 2007, p. 118). Of course, not all claims that organisms are categorically different from machines amount to defining this difference in terms of a deeper interiority or selfhood. But increasingly, from the late eighteenth century onwards, and into twentiethcentury phenomenology (and its embodied variants), the emphasis is on the latter, as is also manifest in Varela's insistence in his last essays on a 'firstperson science' (Varela and Shear eds., 1999). We might say that the extent to which Canguilhem is committed or not, to the presence of a foundational

\footnotetext{
${ }^{13}$ Letter to Hoffmann of September 17, 1699, in Hoffmann 1749, I, pp. 49a-b; cf. De ipsa natura (1698), § 3, GP IV, p. 505; Leibniz 1969, p. 95.

${ }^{14}$ Kant 1987, § 75, pp. 282-283; Kant 1755, Ak 1, p. 230. For a nice discussion which makes Canguilhem a phenomenologist see Gérard 2010; for an equally compelling reading which seeks to distance Canguilhem from phenomenology, see Sholl 2012 and especially Sholl (ms.). I am closer to Sholl's interpretation - and Canguilhem's rather pointed barbs at the expense of Husserl and in favour of Foucault (e.g. in Canguilhem 1967), should be taken into account here - but it must be recognized that there are elements in Canguilhem which lend themselves to Gérard's reading.
} 
subjectivity either 'in the body' or as an irreducible feature 'of the body', is the extent to which he is a phenomenologist. On this issue - which recent scholarship has treated less than univocally -

Canguilhem was a self-proclaimed vitalist (although with a degree of irony), a 'biochauvinist' in the sense that as a thinker of the normal and the pathological, of a 'knowledge of life', as a disciple of Goldstein, he is one of the main figures of what was known as 'biophilosophy' in the mid-twentieth century - a project which differs from present philosophy of biology in a variety of ways (Gayon 2010), notably, that biophilosophy feels that philosophy, sometimes even metaphysics, can dictate its conditions to biology, since living beings have features (value? purposiveness? consciousness?) that remain inaccessible to quantitative science. In contrast, the philosophy of biology is very much a project engaged in conceptual clarification of 'emerged' science, which it does not challenge. However, even qua biophilosopher, it bears noting that Canguilhem lacks the hostility to evolutionary thought found e.g. in Goldstein and Varela, just as he lacks the potentially reactionary appeal to return to a lost Aristotelian world (as in Jonas and Grene).

Some biophilosophers stand at a greater distance from mainstream science than others. Goldstein, sounding quite close to the ideas Canguilhem was to make famous in The Normal and the Pathological, holds that "an organism that actualizes its essential peculiarities or - which means the same thing - meets its adequate environment and the tasks arising from it, is 'normal"' (Goldstein 1934/1995, p. 325). Perhaps unconsciously paraphrasing Goldstein, Jonas in a late piece describes organisms as "things whose existence is their own achievement. That means that they only exist because of what they are doing," which he then explains as "their activity as such is their being" (Jonas 1992, p. 82). While this is not in line with mainstream biology (whether molecular, evolutionary, developmental, etc.), it is not explicitly antinaturalist; and it is also a weak form of biochauvinism, in that it is less a substance (a set of empirical features), and more a function or activity which is being invoked as uniquely organismic. In contrast, Raymond Ruyer's 
insistence on how the organism transcends the spatial realm, maintaining itself through time due to its "potential," which does not itself belong to the space-time world, is more of a revisionary metaphysics. For Ruyer, organisms possess a unity beyond spatial categories; they are fundamentally historical in character (Ruyer 1946, pp. 8, 14, 27, 58, 94). Ruyer appears to be afraid of a universe composed of inanimate matter, with shocks and displacements explainable exhaustively by the laws of mechanics - a universe in which the organism is no longer anything more than a machine: "If you are shocked by what amounts to a generalized 'theory of organism', . . . you had better see clearly that the choice is between this theory and that of a 'generalized molecule" (Ruyer 1952, p. 166).

I have tried to distinguish between a series of views, not identical with one another, in which a valuative term variously called 'the organism', 'the (lived) body', 'Life' and so on, is presented in special in different ways, and usually opposed to the rest of physical nature. While Canguilhem shares the intuition that an organism is always 'actualizing a potential', in a dynamic relation between a plurality of norms and an environment which is made 'one's own' (an Umwelt), he does not oppose modern biology, and is certainly not seeking to "reintroduce the subject into biology," unlike Varela (Weber and Varela 2002, p. 117). He is arguing from properties of existing biological entities - sometimes cells, sometimes monsters or environments, but most often persons, whether considered as agents or as patients. As he says in the Introduction to the Normal and the Pathological, he is not so presumptuous as to claim that he could renew medicine by incorporating a metaphysics into it (Canguilhem 1972, p. 9). I have not tried here to articulate a 'Canguilhemian philosophy of medicine' (some have: Trnka 2003); doubtless it would resemble in some important ways, reflection on the importance of a 'patient-centred' medicine, and would pay close attention to the Goldsteinian and Canguilhemian focus on how the organism (or person, or patient) is a creator of norms (of stability, of health, of survival and so on), in a partly constructivist sense. Yet if we wish to take Canguilhem seriously, some of the 
metaphysics, the biochauvinism, the existential dimension in his thought take us beyond the practical concerns of an empirically focused philosophy of medicine.

Perhaps we should distinguish between three basic claims: strong vitalism, with a metaphysical foundation; biochauvinism, which is more of a 'spontaneous scientific form' of vitalism, stripped of all or most of its metaphysical commitments but definitely tending towards a holistic, organismic perspective; and Canguilhem's view, which of course he never names, enjoying as he does the play of aporias and the mask of the scholar. We could speak of a non-metaphysical vitalism, or a 'naturalized vitalism'15 but then we run into difficulties in accounting for the passages where he speaks of an irreducible, experiential dimension of life; we could say that to the biochauvinistic claims of theoretical biology, he adds an existential dimension. Yet Canguilhem doesn't seem to succumb to the temptation of a bottomless interiority, inwardness or privacy and its concomitant transcendence. Somewhere in between the cold appeal of the inorganic, and the (hot?) mesmerism of transubstantiation - at some distance, then, from the fascination with a kind of transcendence of the flesh found in Merleau-Ponty, Varela or Thompson, where biochauvinism verges on the mystery of transubstantiation - Canguilhem's vitalism, his biochauvinism, his quirky appeals to the "truth of my body" (2008b, p. 475) if not his residual existentialism may hold some lessons for present-day thinking about embodiment, neither obsessively reductionist, nor whimsically holist.

\section{References}

\footnotetext{
${ }^{15}$ Thanks to Pierre-Olivier Méthot for this suggestion. For a related idea of a 'functional vitalism' (as opposed to the metaphysical variety) see Wolfe 2011a.
} 
Barberousse A., Morange M., Pradeu T., eds. (2009). Mapping the Future of Biology: Evolving Concepts and Theories. Dordrecht: Springer.

Bechtel W. (2007). "Biological mechanisms: Organized to maintain autonomy." In F. Boogerd, F.J. Bruggeman, J-H.S. Hofmeyr, and H.V. Westerhoff, eds., Systems Biology: Philosophical Foundations (pp. 269-302). Amsterdam: Elsevier.

Bennett, J. (2010a). Vibrant Matter: A Political Ecology of Things. Durham: Duke University Press.

Bennett, J. (2010b). "A Vitalist Stopover on the Way to a New Materialism." In D. Coole \& S. Frost, eds., New Materialisms: Ontology, Agency, and Politics (pp. 47-69). Durham: Duke University Press.

Bianco, G. (2013). "At the origins of Georges Canguilhem's 'Vitalism.' Against the Anthropology of Irritation." In S. Normandin and C.T. Wolfe, eds., Vitalism and the scientific image in post-Enlightenment life science, 1800-2010 (pp. 243-267).

Dordrecht: Springer.

Canguilhem, G. (1965a). "Aspects du vitalisme" [1946-1947]. In La connaissance de la vie, revised edition (pp. 83-100). Paris: Vrin. (First published 1952)

Canguilhem, G. (1965b). La connaissance de la vie, revised edition. Paris: Vrin. (First published 1952)

Canguilhem, G. (1967). "Mort de 1'homme ou épuisement du Cogito ?" Critique, 242: 599-618

Canguilhem, G. (1972). Le Normal et le pathologique, 3d revised edition. Paris: PUF. (First published 1943)

Canguilhem, G. (1977). La formation du concept de réflexe aux XVIIe et XVIII siècles, $2^{\text {nd }}$ revised edition. Paris: Vrin. (First published 1955).

Canguilhem, G. (1992). "Le Cerveau et la Pensée" (1980). In E. Balibar, D. Lecourt et al. eds., Canguilhem, philosophe, historien des sciences (pp. 11-33). Paris: Albin Michel.

Canguilhem, G. (2002). "Puissance et limites de la rationalité en médecine" (1978). In Études d'histoire et de philosophie des sciences concernant les vivants et la vie (pp. 392-411). Paris: Vrin.

Canguilhem, G. (2002). "Le problème des régulations dans l'organisme et la société." In Canguilhem, Écrits sur la médecine (pp. 101-125). Paris: Éditions du Seuil.

Canguilhem, G. (2002). "Qu'est-ce que la psychologie?” (1958). In Canguilhem, Études d'Histoire et de Philosophie des Sciences (pp. 365-381). Paris: Vrin 
Canguilhem, G. (2008a). Knowledge of Life. Eds. P. Marrati \& T. Meyers; trans. S. Geroulanos \& D. Ginsburg. New York: Fordham University Press.

Canguilhem, G. (2008b). "Health: Crude Concept and Philosophical Question" (translation of "La santé, concept vulgaire et question philosophique" (1988), by T. Meyers and S. Geroulanos). Public Culture, 20(3): 467-477

Clark, A. (1997). Being There. Cambridge, MA: MIT Press.

Clark, A. (2008). "Pressing the flesh: a tension in the study of the embodied embedded mind?” Philos. Phenomenol. Res., 76(1): 37-59

Dailey, P. (2011). "Children of Promise: The Bodies of Hadewijch of Brabant." Journal of Medieval and Early Modern Studies, 41(2): 317-343

Deleuze, G. (1981). Francis Bacon. Logique de la sensation. Paris: Éditions de la différence, réédition, Seuil, 2002.

Deleuze, G. (1993). Critique et clinique. Paris: Minuit.

Deleuze, G., Guattari, F. (1991). Qu'est-ce que la philosophie ? Paris: Minuit.

Descartes R. (1964-1974). OEuvres, eds. C. Adam \& P. Tannery, 11 vols. Paris: Vrin (cited as AT followed by volume and page number)

Descartes R. (1985). The Philosophical Writings of Descartes, eds. J. Cottingham, R. Stoothoff \& D. Murdoch. Cambridge: Cambridge University Press (cited as CSM followed by volume and page number)

Di Paolo, E. (2009). “Extended Life.” Topoi, 28: 9-21

Driesch, H. (1914). The History and theory of vitalism, trans. C.K. Ogden. London: Macmillan.

Elsasser, W. (1961). "Quanta and the concept of organismic law." Journal of Theoretical Biology, 1(1): 27-58

Foucault, M. (1989) "Introduction" (1985). In Canguilhem, The Normal and the Pathological, trans. C. Fawcett. New York: Zone Books.

Gayon, J. (2010). “Vitalisme et philosophie de la biologie." Répha, 2: 7-18. Reprinted in P. Nouvel, ed., Repenser le vitalisme - Histoire et philosophie du vitalisme. Paris: PUF, 2011

Gérard, M. (2010). "Canguilhem, Erwin Straus et la phénoménologie : La question de l'organisme vivant." Bulletin d'analyse phénoménologique, VI(2) : 118-145, http:// popups.ulg.ac.be/bap.htm

Geroulanos, S. (2009) . "Beyond the Normal and the Pathological: Recent Literature on Georges Canguilhem." Gesnerus, 66(2): 288-306 
Giroux, E. (2010). Après Canguilhem : définir la santé et la maladie. Paris: PUF.

Goldstein, K. (1939/1995). The Organism: a holistic approach to biology derived from pathological data in man. New York: American Book Company / New York: Zone Books. (A translation of Der Aufbau des Organismus, 1934.)

Greco, M. (2005). “On the Vitality of Vitalism.” Theory, Culture \& Society, 22: 15-27

Grene, M. (1968). Approaches to a Philosophy of Biology. New York: Basic Books.

Grene, M. (1974). The Understanding of Nature: Essays in Philosophy of Biology. Dordrecht: Reidel.

Grene, M. (2000). “The philosophy of science of Georges Canguilhem: A transatlantic view." Revue d'histoire des sciences, 53(1): 47-63

Hegel, G.W.F. (1970). Encyclopedia of the Philosophical Sciences in Outline (1817), vol. 2, Philosophy of Nature, trans. A.V. Miller. Oxford: Oxford University Press.

Hill, E. (1968). "Materialism and Monsters in the Rêve de D'Alembert." Diderot Studies, 10: $67-93$

Hoffmann, F. (1749). Operum omnium physico-medicorum supplementum primum. Geneva: Fratres De Tournes.

Jonas, H. (1966). The Phenomenon of Life. Towards a Philosophical Biology, New York: Harper \& Row / Dell.

Jonas, H. (1992). Philosophische Untersuchungen und metaphysische Vermutungen. Frankfurt am Main: Insel.

Kant, I. (1900-). Kants gesammelte Schriften, ed. E.Adickes et al. Berlin: Prussian Academy of Sciences (now Berlin-Brandenburg Academy of Sciences). (Ak)

Kant, I. (1987). Critique of Judgment (1790), trans. W. Pluhar. Indianapolis: Hackett.

Kass, L.R. (1995). "Appreciating The Phenomenon of Life.” Hastings Center Report 25(7): 3-12

Leibniz, G.W. (1969). Opuscules philosophiques choisis, trans. P. Schrecker. Paris: Vrin.

Leibniz, G.W. (1978). Die Philosophischen Schriften, ed. G.J. Gerhardt, 7 vols. Reprint, Hildesheim: Georg Olms. (GP)

Machery, E. (2012). "Why I stopped worrying about the definition of life... And why you should as well." Synthese, 185: 145-164

Merchant, C. (1980). The Death of Nature: Women, Ecology, and the Scientific Revolution. New York: Harper and Row. 
Merleau-Ponty, M. (1962). Phenomenology of Perception, trans. C. Smith. London: Routledge Kegan Paul.

Méthot, P.-O. (2013). "On the genealogy of concepts and experimental practices: Rethinking Georges Canguilhem's historical epistemology." Studies in History and Philosophy of Science, 44: 112-123

Moreno, A. \& Mossio, M. (forthcoming). Biological autonomy. A philosophical and theoretical enquiry. Dordrecht: Springer.

Mossio, M., Moreno, A. (2010). "Organisational closure in biological organisms." History and Philosophy of the Life Sciences, 32: 269-288

Normandin, S. and Wolfe, C.T., eds. (2013). Vitalism and the scientific image in postEnlightenment life science, 1800-2010. Dordrecht: Springer.

Novalis (1987). Vorarbeiten (1798), in Werke, Tagebücher und Briefe, ed. H.-J. Mäh1 and R. Samuel, 3 vols., vol. 2: Das philosophisch-theoretische Werk, Munich: Carl Hanser Verlag.

Oyama, S. 2010). "Biologists behaving badly: Vitalism and the language of language." History and Philosophy of the Life Sciences, 32: 401-423.

Perret, N. (2012). "A Symmetrical Approach To Causality In Biology." Philosophia Scientiæ, 16(3): 177-195

Peterson, E.L. (2012). “'Neither camp will have me': C. Lloyd Morgan, Joseph Needham, J. H. Woodger, and the early-20th century attempt to devitalize holism." Presentation at conference on Hasard, holisme et réductionnisme dans les sciences de la vie, Paris, ENS, Centre Cavaillès (May 2012)

Peterson, E.L. (2013). "The Conquest of Vitalism or the Eclipse of Organicism? The 1930s Cambridge Organiser Project and the Social Network of Mid-Twentieth Century Biology." British Journal for the History of Science (forthcoming).

Ruyer, R. (1946). Éléments de psycho-biologie. Paris: PUF.

Ruyer, R. (1952). Néo-finalisme. Paris: PUF.

Schaeffer, J.-M. (2007). La fin de l'exception humaine. Paris: Gallimard.

Sholl, J. (2012). “The Knowledge of Life in Canguilhem's Critical Naturalism.” Pli, 23: 107-127.

Sholl, J. ms. "Problematizing a Phenomenology of Life: Goldstein, Merleau-Ponty and Canguilhem."

Simeonov, P.L., Brezina, E.H. et al. (2012). "Stepping beyond the Newtonian Paradigm in Biology." In Simeonov, P.L., Smith, L.S., Ehresmann, A.C., eds., Integral Biomathics (pp. 319-418). Dordrecht: Springer. 
Starobinski, J. (1956). L’idée d'organisme. Paris: Centre de Documentation Universitaire / Collège philosophique.

Sutton, J., Tribble, E.B. (2011). "Materialists Are Not Merchants of Vanishing: Commentary on David Hawkes, 'Against Materialism in Literary Theory'." Early Modern Culture 9, http://emc.eserver.org/1-9/sutton_tribble.html

Thompson, E. (2007). Mind in life: biology, phenomenology, and the sciences of mind. Cambridge, Mass.: Harvard University Press.

Trnka, P. (2003). Subjectivity and Values in Medicine: The Case of Canguilhem. The Journal of Medicine and Philosophy, 28(4): 427-446

von Uexküll, J. (2010) A Foray Into the Worlds of Animals and Humans, with A Theory of Meaning (1934), trans. J. D. O'Neil. Minneapolis: University of Minnesota Press.

Varela, F., Shear, J., eds. (1999). The View from Within. First person approaches to the study of consciousness. Exeter: Imprint Academic.

Weber, A., Varela, F.J. (2002). "Life after Kant: Natural purposes and the autopoietic foundations of biological individuality." Phenomenology and the Cognitive Sciences, 1: 97-125.

Wheeler, M. (2010). "Mind, things and materiality." In Malafouris L., Renfrew C., eds. The cognitive life of things: recasting the boundaries of the mind (pp. 29-37). Cambridge: McDonald Institute for Archaeological Research Publications.

Wolfe, C.T. (2010). "Do organisms have an ontological status?". History and Philosophy of the Life Sciences, 32(2-3): 195-232

Wolfe, C.T. (2011a). "From substantival to functional vitalism and beyond, or from Stahlian animas to Canguilhemian attitudes," Eidos, 14: 212-235

Wolfe, C.T. (2011b). "Vitalism," in M. Gargaud et al., eds., Encyclopedia of Astrobiology (pp. 1749-1750). Berlin: Springer.

de Issekutz Wolsky, M., Wolsky A.A. (1992). "Bergson's vitalism in the light of modern biology." In F. Burwick \& P. Douglass, eds., The crisis in modernism. Bergson and the vitalist controversy (pp. 153-170). Cambridge: Cambridge University Press. 